\title{
THE REVIVAL OF THE VILLAGE.
}

A REACTION against centralisation is one of the notes of the present day, a note which, I venture to think, will be heard with more and more insistency as the century gets older, because it results from the conditions involved by the progress of modern invention and discovery, psychological and physical. Increased facilities of communication tend for a time to increase of centralisation, but push these still further and the contrary effect emerges : for they tend to put an increasingly large area on the same level in this respect as the towns themselves, and therefore enable manufacturers to set up elsewhere and large numbers to settle outside the larger towns without feeling cut off from the movement of life. At the same time the smaller groups thus forming and enlarging yearly in the outskirts of our great cities are not, it may be justly objected, villages but suburbs; i.e., though they may develop a local life they are economically directly dependent upon the city and not upon the land. The village is essentially the headquarters of a group economically directly dependent on the land. It is of course a matter of general knowledge that during the last half of the eighteenth and the whole of the nineteenth century all causes combined to bring about the decay of the villages of England. The loss of independence and prosperity of the people owing to the enclosures, together with the attraction of the increasingly accessible towns and colonies, drew away the more adventurous of the young men. The policy of the squires acted in the same direction. More labourers meant more old people on the rates; cottages were expensive to build and keep up; small farming was antiquated and large farms worked largely by machinery gave less trouble all round and were the proper thing; more villagers meant more possible poachers and were for every reason undesirable. Of late years, however, it has been realised by an increasing number that it is not a matter of indifference to a country whether or not it has a proportion of agriculturists. It is found that big towns not only have a lower standard of physique, but actually have to be fed by a constant stream of immigration from the country because they do not reproduce themselves after the third generation; further, that country life and occupations at their best develop a human type whose existence is of importance to the nation in itself and apart from the need of stocking the towns. The revival of the village should therefore be looked at as a matter of national importance, and is felt to be such by a small yet increasing number.

What are the characteristics of the village life which help to create this type where the system is in full development? They are: seasonal work dependent on the round of the year and punctuated by seasonal festivals; a diffusion of private property together with the exercise of common rights; a wealth of tradition expressed in song, story, and dance, and thus the power and habit of making amusement in the village without the need to seek it 
ready-made in the nearest town; the education-by the influences of work, folk, and place-of hand, heart, and head, of which the modern agricultural labourer is too often, and the modern townsman almost invariably, deprived. All this has been at the most flourishing period of the village system gathered up and expressed in the village church, with its holy wells and local shrines, its perambulations of the village bounds, its local feast and Christian calendar. The modern English village knows little of it; the English village is slowly dying, and the modern English rustic is a manufactured article. The revival of the village must therefore be attempted on more lines tilan one; it must aim at re-creating all the elements of a self-supporting rural community. These efforts may be for convenience divided into :-

(1) The attempt to deal through Acts of Parliament with land and housing conditions;

(2) The attempt to revive village handicrafts as supplementary, or in exceptional cases alternative, occupations for villagers;

(3) The attempt to revive the old songs and dances and to stimulate an interest in acting and drama, together with flower-shows and village institutes providing newspapers and books;

(4) The attempt to induce villagers to co-operate for common purposes, especially in such simple ways as

(a) the formation of cow-clubs for the provision of milk,

(b) for credit, so much needed by small holders,

(c) for the purchase and sale of commodities,

(d) for the joint holding of land to be severally cultivated,

(e) for the building and ownership of cottages.

The dearth of cottages in most country villages is notorious, and is in some ways the most urgent aspect of the question of village revival. There are, of course, many villages where at present cottages cannot be built except by the charity of the squire, because wages are too low to make a paying rent possible. There are others where the possession of a large garden or small allotment with the cottage, and the fact that cottages can be built cheaply for one reason or another, makes it possible for a paying rent to be paid, provided the land can be obtained cheaply enough. There is, however, as a rule no one whose business it is to go into the matter and see what can be done. The villagers themselves are not in a position to do so-being, we must remember, as they are, manufactured articles-and so the cottages do not usually get built even in such cases. There is now an association, the Rural Co-partnership Housing Association, which exists to form local societies which shall undertake this work. It provides them with model rules, with help and advice, and it is associated with the Rural Co-partnership Housing Trust which will invest in approved Societies as far as its resources permit, provided certain conditions are satisfied. Such societies expect tenants to become members, taking up a $\oint_{1}$ share for which they pay gradually and going on to $\ell_{5}$. Surplus profits above 5 per cent., if any, go to the tenantmembers, when provision has been made for depreciation, etc., and they enjoy security of tenure provided they respect the rights of 
other tenants and do not disregard certain simple regulations as to over-crowding, etc. Tenant members may cultivate a garden only, or they may be small holders and hold twenty or thirty acres; the system is very elastic. The Association is at present at work in a few cases only but is likely to spread considerably in the next few years. At Dachet, near Windsor, a number of allotment holders who would otherwise have lost their allotments, have been formed into a society owning thirty acres in which sixteen cottages are built, twelve more are nearly finished. At Otford, near Sevenoaks, 160 acres have been acquired; thirteen cottages are being built for small holders taking from one to twenty acres, while others with half an acre only are in contemplation. At Somersham, Hunts., a fruit-growing district, cottages are being built to be let with one or two acres or less; twenty in all are to be built, and two are already completed. At St. Mawes, Cornwall, a society is being started which will build for the fishermen whose ruinous old cottages will be done up at considerable expense for the summer visitors. These are instances merely of what is being done already.

These societies own their own land, or they may build upon publicly owned land. In any case, the cottages do not become the property of the individual tenant but are collectively owned. They thus serve to build up that sense of membership in a community which modern life, even village life, tends so much to lessen. All forms of co-operation have this valuable result and are indeed indispensable for this if for no other reason in the revival of the village. The suspicion of each other, as well as of the better off, which is one of the most characteristic traits of the modern rustic mind, must be changed into a different attitude if the revival of the village is to be a reality. It would be strange if they were not suspicious when we remember how much they have lost by the enclosures, how all the circumstances of their present lives make for isolation, and how extremely poor they are. But such an atmosphere is not one which can produce an ideal community, - rustic or otherwise. By the spread of co-operation the villages can be made to see that their interests are one with their neighbours, .and this habit of acting together will naturally result in a different spirit from that now prevalent. Societies for the joint holding of land are vigorously promoted by the Agricultural Organisation Society, as well as others for purchase and sale of commodities, and both forms are making considerable headway. Credit societies are absolutely essential for rural development, but so far they have made little progress in this country for want of a large central association in possession of funds or credit.

In regard to the revival of folk song and dance much is being done by the Esperance Club and by Mr. Cecil Sharp and the Folk Song Society, while flower-shows and village institutes are sporadic everywhere. Village bands are being resuscitated, and with them come dances on the green once more, as well as in the village hall or institute in the winter. The revival of handicrafts is terribly hampered by the lack of organisation for sale. Much has been done, as far as weaving is concerned, by organisation for sale in regard to Scottish and Irish industries, but hardly anything for 
English, while such industries as local pottery, carving, ironwork, etc., are likewise at a disadvantage.

As regards Acts of Parliament dealing with land and housing something has been done, but little as compared with the need. The Small Holdings Act works in some counties but not in others, the last Housing and Town-planning Act practically not at all in rural districts.

It has been well said that there are two ways in which the State can interfere with the actions of men and women: by way of restraint, the paternal way; by way of guidance and encouragement, the maternal way. There is a tendency in the modern State to pass from the first to the second method, but here England lags behind. We still cling too largely to what may be best described as a flabby paternal line. Thus laws are enacted which aim feebly at forcing landlords to give up land when required for small holdings, and obliging local authorities to house the people when this appears necessary. The State now forces everybody to make provision for sickness; it obliges people to send their children to school. On the other hand it does not even allow, without special permission from the Local Government Board, and certainly does not encourage, local authorities to buy land in excess of any immediate demand for any purpose that may seem good to them, such as ensuring that sufficient land shall be kept open for public recreation and enjoyment, as is often done in Germany, on a large scale, or to provide for a probable future demand for small holdings or housing. Nor has it so far seen fit to encourage enterprise by setting up a Central Co-operative Bank to deal with the finance of local societies.

In France and Germany great encouragement is given to such institutions, and they are at work on a very large scale. Here the idea of the State as necessarily occupied rather in repressing crime and enforcing regulations than in encouraging such desired developments seems to hold the field to a far greater extent. Thus while State organisation for the sale of village industries or to assist co-operative agricultural developments is probably outside the range of practical politics here, except in the shape of grants for propagandist work, Austria does much, I understand, for the sale of village industries of Bosnia and Herzegovina, while Denmark devotes its energies largely to the organisation of the sale of dairy produce. The prevalent State attitude would matter little if things were being done privately in a satisfactory way; but this is so far from being the case that there is no country where village handicrafts have a more difficult struggle than in England, or where the small man finds it harder to get credit, while comparatively few people even now realise the importance of these matters as a whole to the nation. Sometimes an attempt is made to utilise one or other as a plank in party politics. The re-creation of the village, however, is not a matter of party politics : it is a problem of national concern, and should be thought of as essential to a general policy of revival of country life as necessary to the future of England.

Sybetla Branford. 